\title{
Folklore as a Factor Contributing to the Polish-Czech Integration on the Example of the World Festival of the Polish Community Folk Groups
}

Ewa Barnaś-Baran / e-mail: ewa.bb@ur.edu.pl

Zakład Historii i Teorii Wychowania, Instytut Pedagogiki, Uniwersytet Rzeszowski, Polska

Barnaś-Baran, E. (2020). Folklore as a Factor Contributing to the Polish-Czech Integration on the Example of the World Festival of the Polish Community Folk Groups. Czech-Polish Historical and Pedagogical Journal, 12/2, 97-111.

https://doi.org/10.5817/cphpj-2020-024

In 2019 in Rzeszoin the XVIII World Festival of the Polish community folk groups was held. The festivals have been organized since 1969, being the Song and Dance Group of Olza one of their most frequent participants. Rzeszow hosted other groups from the Czech Republic which were equally successful. The groups are widely-recognized in their own country receiving many prizes and awards in there. The paper indicates the different dimensions of Polish-Crech integration, namely personal, linguistic, educational, cultural and behavioral. The activities undertaken by the concert organizers as well as the individual effort of the participants and the audience alike made that creating the community, integration and building contacts between different nationalities, regions and cultures was possible. The main source constituted the materials collected at the Centre of Research on the Poles and the Polish community in the world of the University of Rzeszon as well as the press articles published locally and nationally.

Key words: integration; the World Festival of the Polish community Folk Groups; Rzeszón; folkelore; Olza

The research on the folklore of Polish lands began in the $19^{\text {th }}$ century. The schedule was prepared by Hugo Kołataj in 1802 but the increase of interest in this research area dates back to the $\mathrm{mid}-19^{\text {th }}$ century. The scientific activity, conducting research and its documenting was caused by recognizing folk culture as a cornerstone of national identity. Deeper understanding was encouraged by the need to maintain this very sense, being it constantly and purposely suppressed by the governments of the neighboring countries during the annexations. It was Oskar Kolberger (1814-1890), a Polish ethnographer and folklorist who prepared a collection of monographs on a local culture. Their number, published during his lifetime, reached 33 volumes and was considered a breakthrough in this field of study. At stated by Kolberger in the aforementioned, family home and the family were crucial in constituting the sense of belonging to a particular community. ${ }^{1}$

1 Kolberg, O. (1910). Tarnów-Rz̧ešón: materialy etnograficzune, oprac. S. Udziela, Kraków, p. 4, 8. 
Another important factor were songs and chants accompanying people not only during their housework but also at leisure. The development of the nationalist movement in the Second Republic was the next step towards conducting research on the culture of particular regions. After the Second World War it was continued, as shown by the re-edition of the Kolberger's milestone work. At present, there is a clear distinction between the so-called traditional approach towards regional research started in the $19^{\text {th }}$ century. and the next stage of the so-called new regionalism started at the beginning of the $21^{\text {st }}$ century, being it mostly economically-driven. ${ }^{2}$

A new chapter of popularizing Polish national culture after the Second World War began with the National Festival of Folk Music held in 1949 in Warsaw. ${ }^{3}$ The next stage of coming back to the origins of national culture as well as folk art took place at the very start of 1970s in such countries as France, Italy and Belgium. The similar trends could be observed in Poland. As noted by Daniel Kadłubiec, a literary historian, ethnographer, collector, researcher and theorist working at the Pedagogical Institute in Ostrava, the University in Prague and in Katowice, in the 1970s the effort of becoming familiar with the diversity of folk culture of one's own region and its popularization was put by the teachers or other non-professionals. ${ }^{4}$ In the area of his interest, there was the culture of the Cieszyn Silesia which, as he claimed would be hard to remain indifferent to.

He strongly believed that this land was extremely rich in plots and motifs. ${ }^{5}$ What the folk art lovers had in common was the enthusiasm of a researcher, emotional approach to the related topic, being a patriot, especially on a small scale related to their little homeland. The lives of many connected with folklore, regardless of their country of residence, was full of love towards the folk art and they could not imagine this life without it. ${ }^{6} \mathrm{~A}$ way of popularization of this crucial, not only in social but also patriotic context became the concerts and folk festivals. These were, among the others, highly popular and widely anticipated the International Festival of the Folklore of the Mountain Lands in Zakopane, held annually, the Festival of Folk Groups in Kazimierz, the Festival of Herody in

2 Markocka, M. (2014). Regionalizm w Polsce - tradycja i współczesność (wybrane zagadnienia). „Seminare. Posqukiwania naukowe“, t. 35, nr 3, p. 151.

3 Dynia, J. (2015). Dokumentowanie folkloru. Nagroda im. Oskara Kolberga dla Radia Rzeszów. „Nasz. Dom Ržesæów: miesięrznik spoteczno-kulturalny“, nr 1, p. 10.

4 Ptyniesz Olzo... Zarys kultury duchowej ludu cieszyńskiego (1970), red. D. Kadłubiec, Ostrawa, p. 8, 49; PZKO 1947-2017. 70 lat na stras்y dziedzictwa kulturowego Polaków w RC (2017), Czeski Cieszyn, p. 132.

5 Kadłubiec, D. (1938). O opowieściach ludu znad Olzy. In Płyniesz. Olzo..., p. 57; Stiasny, B.: (1938). Cieszyn i Zaolque: prọewodnik, Cieszyn, p. 14, 20. Autor podkreślał bogactwo sztuki ludowej tamtych terenów.

6 Kopała, M. (2009). Życie folklorem pisane- portret Stanisławy Mróz. „Głos Gminy Grębów“ p. 15. p.14-15. 
Będzin or the Festival of Sabatowe bajania in Bukowina Tatrzańska, the Rzeszów Folk Fair in Mielec or the Folk Festival in Płock included. ${ }^{7}$ The opportunity to see the national and regional dances or to listen to the accompanying songs was more than appreciated. The intertwining of themes of religion, love and war (war and glory) caught the eye of many. Being joy to some extent the factor that all the dances had in common, it created a point of reference not only for the nations but the whole generations. ${ }^{8}$ In the $21^{\text {st }}$ century. music, dance and singing is still considered to be the most universal form of communication all over the world, contributing to the fact that the folk concerts have many followers. ${ }^{9}$ As rightly said by Henryk Jasiczek referring to Władysław Gębin's words, regionalism is a form of noble and meaningful patriotism. It shows the love of one's own country by the sense of knowing and loving of their homeland. ${ }^{10}$ Regionalism can also lead to numerous cultural events, development processes but on the basis of historical facts and events, to learning new skills, dancing and singing in particular, building bridges over time and creating a system of reference for generations. ${ }^{11}$ As stated by Jerzy Dynia, the current Podkarpackie Province can also be seen as one of the regions where folklore is very popular. ${ }^{12}$ The experience of Polish folklore, the integration of the representatives of different nations, generations, knowing the songs and dances of the countries of residence of the dancers and other participants is something the guests and the residents of the Podkarpackie and of Rzeszów but not only has been a part of since 1969.

The World Festival of the Polish community Folk Groups has been organized in Rzeszów since July 1969 and the Centre of Research of the Poles and the Polish community in the world at the University of Rzeszów has been there since $2014 .{ }^{13}$ From 1969 to 2019 there were 18 festivals of the Polish community in which over 200 groups participated.

The aim of the following paper is to present the meetings during the festival, taking place every three years in July in Rzeszów, a part of the World Festival of the Polish community as an important element of building Polish-Czech relationships but also making them closer. The presented, selected ways of popularization of

7 Grygiel, J. (1970). Uroki i pożytki folkloru. „Widnokrag” 4. 07. 1970, nr 27, p. 1; pp. 1-2.

8 Czerniawski, K. (1860). O tańcach narodowych z.pogladem historycznym i estetycznym na tańce różyych narodów a w szçególności na tańce polskie. Warszawa, pp. 2-3, 8, 9.

9 Zatorski, R. (2010). W tańcu i śpiewie. W przekazie „Bandoski“ folklor wzbudza podziw. „Nasz Dom Rzeszón: miesięrnik społeczno-kulturalny“, nr 8, p. 17.

10 Jasiczek, H. (2016). Nasz region i regionalizm, Płyniesz Olzo. Monografia kultury ludowej Ślaska Ciessynnskiego, oprac. D. Kadłubiec z zespołem, Czeski Cieszyn, p. 21.

11 Idem., p. 21.

12 Dynia, J. (2018). Wielkie święto folkloru. W urokliwym Kazimierzu Dolnym nad Wisłą. „Nasz Dom Rz̨eszón: miesięrnik społeczno-kulturalny“, nr 7, p. 16.

13 Bonusiak, A. (2019). Wstęp In Co træeci lipiec nasðym sercem bije...Ś wiatowe Festiwale Polonijnych Zespołów Folklorystycznych w Rzeszowie 1969-2019, Rzeszów, p. 8. 
folklore, the regional and national and heritage constituted the factors contributing to the integration of the Poles, the Polish community and the Czech, playing the Polish community groups from the Czech Republic the key role. The frequent performance of the Song and Dance Group of Olza remains of special importance. The paper is based on the archive materials gathered at the Centre of Research on the Poles and the Polish community in the world of the University of Rzeszów and the Rzeszów branch of Wspólnota Polska Association. ${ }^{14}$ The press articles published in the local press, especially those covering widely the festivals of the Polish community in Rzeszów were also analyzed. These included, Nowiny (published daily), Nasz. Dom Rzeszón-miesiecznik społeczno-kulturalny (published monthly), Trendy Podkaprackie, Echo Rzeszowa and other newspapers and magazines from other parts of the region. Furthermore, the paper also makes reference to the press articles published nationally concerning the festival in question.

\section{The World Festival of the Polish community in Rzeszów (1969-2019)}

The activity connected with the Polish community in Rzeszów actually started in 1969. It was the time of coming to town the Song and Dance Group of Krakus from Belgium as a part of their tour in the region. The group was directed by Wanda and Bronisław Stal. As Ryszard Zatorski recollects, it was at their home in Grenk-Zwartberg, Belgium where the idea of the World Festival in Rzeszów came into being. ${ }^{15}$ Thanks to the cooperation between Czesław Świętoniowski, the director of the Provincial Cultural Centre (WDK) in Rzeszów and Władysław Kruczek, the First Secretary of the Regional Committee of the Polish United Workers' Party acting on behalf of the local government, resulted in the project of organizing regular meetings of the Polish community art groups in there. The project was supported by the Association of Polonia since Mieczysław Klimaszewski, its President and the Vice-President of the State Council as well as the Rector of the Jagiellonian University, a scientist-geographer shared the need to build the relationships between Poland and the Polish community. ${ }^{16}$

Two years later, from 20 to 22 of July 1969, during the $25^{\text {th }}$ anniversary of the People's Poland the first festival took place. ${ }^{17}$ It was attended by 12 groups from Europe and one from the US. According to Ryszard Dzieszyński, the choice of

$14 \mathrm{~W}$ przypisach materiały $\mathrm{z}$ wymienionego Centrum podano pod nazwą: Archiwum Dokumentacji Ruchu Polonijnego (dalej: ADRP).

15 Zatorski, R. (2017). Zachowują i odradzają polskość. XVII Świtowy Festiwal Polonijnych Zespołów Folklorystycznych. „Nasz Dom Rzeszón: miesiecznik społeczno-kulturalny“, nr 7, p. 3.

16 Dzieszyński, R. (1989). Siedem sź̨̧̨śliwych festiwali. Lublin, p. 10.

17 Dzieszyński, R. (1989). Siedem sžczéśliwych..., pp. 12-13; Grudzień, M. (2006). Festiwal ponadczasowy. Rzeszów stolica polonijnego folkloru. „Nasz. Dom Rzueszón: miesięcznik spoteczno-kulturalny", nr 7, p. 14. 
Rzeszów as the host city was not a coincidence. He thinks that it resulted from the location of the city in the former Galicia, the region badly affected during the annexations, especially in the $19^{\text {th }}$ century. by poverty. But after the Second World

War the rapid growth made it a perfect place for people with families to emigrate. ${ }^{18}$ Both the press and the radio in Rzeszów decided to cover and popularize the idea of the festivals of the Polish community taking place in

Rzeszów. ${ }^{19}$ Jerzy Dynia, the reporter of Radio Rzeszów and the television recollects that in 2011 taking into consideration the times we were living in, the end of the 1960s, it was something extraordinary, especially that everyone who was coming back from an Iron Curtain was considered to be a spy. The residents of Rzeszów observed it all in disbelief looking forward to what would happen next. ${ }^{20}$

On the $1^{\text {st }}$ July, 1969 the first groups came in, these were Olza from the Czech Cieszyn and the Polish-Hungarian Group in Józef Bem's name from Budapest. ${ }^{21}$ With the Song and Dance Group of Olza, there was a female choir of Hutnik from Trzcyńc. ${ }^{22}$ It was noted by the press that over the years, the groups from various countries, the Czech attended almost every festival, were walking into the city dancing the folk dances like Polonaise and kujawiak. ${ }^{23}$ Noticeably, the groups were not only recognized abroad but also locally. ${ }^{24}$ Thanks to the consecutive fourteen editions of the festival, until 2008 it was possible to see 190 groups from 23 different countries and 4 continents. Mariusz Grudzien, who was the director of the festivals of the Polish community in Rzeszów for many years claimed that the festivals in Rzeszów gave the onset of the Festival of Polish Culture in the US, France, Germany and in the UK. In Poland in turn it started the Festival of the Children's Folk Groups in Iwonicz Zdrój.

As for the genesis of the whole event, he cited Józef Burszta, an outstanding ethnographer, sociologist, historian and a native to the Podkaprackie that the festival came into being a little bit of a coincidence, a little bit of a need. ${ }^{25}$ It turned

18 R. Dzieszyński, Siedem szcz̨ślinyych...., s. 10.

19 Dynia, J. (2015). Dokumentowanie folkloru. Nagroda im. Oskara Kolberga dla Radia Rzeszów. „Nasz Dom Rzeszón: miesięrnik społeczno-kulturalny“, nr 1, p. 10.

20 Gieroń, A. (2011). Hej przyjechali goście. „Trendy Podkarpackie“, nr 3, p. 1.

21 Dzieszyński, R. (1983). Siedem sz̨czéślinych ..., p. 14; Popow, J. (1983) Inicjatorzy polonijnego festiwalu. „Widnokrag: tygodnik spoteczno-kulturalny“, nr 28, p. 1.

22 Dzieszyński, R. Siedem szcześlinych..., p. 15.

${ }^{23}$ ADRP, sygn. T-078, V ŚFPZF, Szli polonezem i kujawiakiem, „Gazeta Festiwalowa“, p. 3. W 1980 r. przyjechały Zespół Regionalny „Gorol“ z Jabłonkowa, Zespół Pieśni i Tańca PZKO „Górnik”, Zespół Pieśni i Tańca PZKO „Olza“ z Czeskiego Cieszyna; Tamże, VI ŚFPZF, k. 79; Woźniak, J. (1983). Rzeszowski festiwal. „Prayjaciótka“; Tamże, VII ŚFPZF, k. 7, Woźniak, J. (1986). Polonijny folklor nad Wisłokiem. „Przekerój“.

24 Bertowicz, A. (1974). Spotkanie z ojczyną. „Widnokrag: tygodnik spoteczno-kulturalny“, nr 28, p. 1.

${ }^{25}$ Grudzień, M. (2006). Festiwal ponadczasowy. Rzeszów stolica polonijnego folkloru. „Nasz. Dom Rzueszón: miesięcznik spoteczno-kulturalny“, $\mathrm{nr}$ 7, p. 14. 
out to be a tremendous success both as a cultural and educational event and the Festival of the Children's Polish community Groups in Iwonicz Zdrój, first held in 1992 became its most desired successor and gave it a sense of continuity. In 2009, the groups with the longest history to perform in Iwonicz included those from Lithuania, Canada, Russia and group of Laczka from the Czech Republic. ${ }^{26}$

The support to organize such a complex event came from the Rzeszów branch of Wspólnota Polska Association, established on the $1^{\text {st }}$ July 1990. It pays special attention to the Centre of Polish dances dedicated to the folk groups and the Choreographic Centre for the Polish community, established in 1998. The latter remains the only form of education of the Poles and the Polish communities living abroad in the world. It makes it possible to gain knowledge and professional qualifications of a teacher and a choreographer specializing in a folk dance. ${ }^{27}$ The Association operates in Rzeszów and takes care of the World Contest of the Polish community Theatres which has been held every two years since 1995. Another important aspect of its activity remains providing social assistance to the Poles in cooperation with the Caritas of the Rzeszów diocese as well as assistance in organizing the holidays of the youth of the Polish origin. ${ }^{28}$

In 2019, it has been 50 years since organizing the first festival of the Polish community in Rzeszów. The groups from the Czech Republic could not miss such an opportunity, Olza, Btedowice and Suszanie included. ${ }^{29}$ During the Gala Concert called the Folklore of the Peoples of the World, commemorating the anniversary and being extremely popular among the residents of the region over the years, the Czech Republic was represented by all the mentioned above groups. ${ }^{30}$ As emphasized by Lesław Weiss, the manger of the festival for many years, it is a very special festival, the only one of this kind in the world where all the participants perform during the Closing Concert. ${ }^{31}$

\section{The Song and Dance Group of Olza}

The Song and Dance Group of Olza operates in the Czech Cieszyn at the Polish Culture and Education Association in the Czech Republic. Established in 1953,

26 Sudyka, R. (2009). Tożsamość tańcem i śpiewem zapisana. „Croscena: krośnieńska scena kultury“, nr 69, p. 9.

27 Bar, J. 4-letnie Polonijne Studium Choreograficzne i jego rola w kreowaniu wizerunku kultury polskiej wśród Polonii i Polaków mieszkających poza granicami kraju. In Co træeeci lipiec..., pp. 87-88.

28 http://wspolnota-polska.rzeszow.pl/stowarzyszenie/historia/, dostęp z dnia 6. 11. 2019.

29 Folder festiwalowy XVIII Światowego Festiwalu Polonijnych Zespotón Folklorystycznych w Rzeszowie 17-25 lipca 2020, p. 3.

30 Tamże, p. 4

31 Zatorski, R. (2017). Korzenie naszej kultury. Paradny folklor na światowym festiwalu w Rzeszowie. „Nasz Dom Rzeszón: miesięcznik spoteczno-kulturalny“, nr 8, p. 3. 
originally, it was the youth song and dance group. The origins date back to the course of folk dance in the Czech Cieszyn by Janina Marcinkowa. ${ }^{32}$ The next instructor, for the following 20 years was a former dancer Janina Ferfecka. ${ }^{33}$ Over the years, the group performed the dances of Cieszyn, Polish regional and national dances, the dances of Czech and Moravia as well as the dances of Slovakia. ${ }^{34}$ Their appearances in Poland started in Tarnowskie Góry, Warmia and Masuria, in Racibórz, in the land of Rzeszów. In 1972 it was noted by the press that the members of the groups (the high school students and students at the time) maintained contacts with the national minorities inhabiting the former Czechoslovakia, Hungary and the people of Ukraine. In Prague and Ostrava, the group attended the so-called Polish Sundays. ${ }^{35}$

In 1969 the group of Olza witnessed an important event in the history of Rzeszów, namely being it recognized as the city of the Polish community art groups and folk groups subsequently. It was noted on a numerous occasions by the press that during the First World Festival of the Polish community groups, which was held at that time, the Song and Dance Group of Olza won the first prize and got the awards during other festivals. It was crucial that almost always the group visited Rzeszów during the festival in July. ${ }^{36}$ In the publication devoted to the anniversary of the group, it was stated that during one of their visits to Rzeszów, the dancers learnt how to dance slide polka of Rzeszów which later on was performed for many years. What's more, the group was presented with a set of the traditional Rzeszów dance costumes as well as 8 sets of the Podhale region dance costumes. ${ }^{37}$ In 1983 Nowiny, the newspaper published in Rzeszów noticed that the ongoing festivals is the time of fun but also hard work of those responsible for hosting the guests from abroad. A clear and significant example of this was Modextra, the studio of folk costumes which work constituted one third of all costumes of the festival participants, including dance costumes of Rzeszów, Cracow, Lublin, Lowicz, Nowy Sacz, Biskupin, the Beskid region, of the nobility and from the times of the Dutchy of Warsaw. It contributed to the great number of ornaments such as sequins, elements with beads, embroidery and sews. ${ }^{38}$

\footnotetext{
32 ADRP, sygn. T-078, k. 1.

33 Dzieszyński, R. Siedem szczéslinyych ..., p. 14; 60 lat Olza, (2014). red. R. Putzlacher-Buchtai inni, Czeski Cieszyn, p. 80.

34 PZKO w roku 2007. Aneks do leksykonu, red. F. Bałon, Czeski Cieszyn, p. 142

35 ADRP, sygn. T-078, I ŚFPZF, Informator 1969, b.k.; Przedstawiamy polonijne zespoty „Olza“, „Nowiny Rzeszowskie“ 14 VII 1972, p. 3.

36 Przedstawiamy polonijne...s, 3; ADRP, sygn. T-078, III ŚFPZF, Laureaci Światowego Festiwalu Polonijnych Zespołów Artystycznych, „Trybuna Ludu“ 20 VII 1974, k. 23.

3760 lat Olza..., p. 28.

38 ADRP, sygn. T-078, I ŚFPZF, k. 13. Pipała, F. (1983). Zespoły Polonijne na Światowy Festiwal w strojach z rzeszowskiej „Modextry”, „Nowiny!
} 
The Song and Dance Group of Olza activity over the years praised the Polish character and friendship verbally but also with singing and dancing. After 35 years, it was estimated that the group performed over 800 times in many cities of the former Czechoslovakia and abroad and its concerts were broadcast by the television in Bratislava and Ostrava. ${ }^{39}$ It can be assumed that the long-term cooperation with Rzeszów and building contacts contributed to the fact that the $50^{\text {th }}$ anniversary of Olza was also celebrated with the dances of Rzeszów performed during the Closing Concert by its former dancers. ${ }^{40}$ Thanks to the managers and the engagement of the group members, the number of places in Poland where they performed gradually increased. In the catalogues and leaflets published by Olza, it was mentioned for many years that the group participated in the World Festival of the Polish community art groups in Rzeszów in parallel with its successful activity in the former Czechoslovakia. ${ }^{41}$ The coverage provided by the local press, especially those praising its members was often referred to. Undoubtedly, one of them remains speaking fluent and sophisticated Polish, making the group stand out from the crowd. To commemorate the $30^{\text {th }}$ anniversary of the group, Nowiny devoted a special article to it in 1983 which stated that the group is full of beans. ${ }^{42}$ It was reminded that during the previous festivals, their performance was always met with standing ovation, bringing in a breath of fresh air. The artistic programme of the group embraced much more than the Polish dances, presenting also the songs and dances of their homeland, the wedding of Cieszyn included. Another three years and it could be read again that the folklore of the Cieszyn region enjoyed great success and became popular among the Polish community groups. The information about the performance of the groups during the following festivals was widely covered by the national press, stating that it could be found among one of the most important events dedicated to the Polish community in the country. ${ }^{43}$ In 1986 during the VII Festival, the group of Gorale from Mosty, the former Czechoslovakia, performing the shepherd's songs and the dances of their own region turned out to be successful. On the pages of Driennik Zachodni it was noted that in Krosno, Olza from Czechoslovakia was highly praised for the lively performance of the dances of Cieszyn. ${ }^{44}$ In 2008 the local press in Rzeszów claimed that Olza was one of the

39 ADRP, sygn. T-078, k. 3. Zespół Pieśni i Tańca ZG PZKO „Olza“; Tamże, Wykazy zespołów 1989 r., k. 2. W 1989 r. przyjechały do Rzeszowa „Olza“, Zespół Pieśni i Tańca „Oldrzychowice“ raz Zespół folklorystyczny „Sucha Górna“.

4060 lat Olza..., p. 120.

41 ADRP, sygn. T-078, k. 30, 71-72. Foldery informacyjne zespołu Olza.

42 Kempf, Z. (1983). Trzydziestolatka „Olza“. „Nowiny“, p. 4.

43 ADRP, sygn. T-078, III ŚFPZF, Rozpoczyna się festiwal polonijnych zespołów folklorystycznych (1983), „Życie Warszawy“.

44 Hadław, R. (1986). Polonijne zespoły zafascynowane śląskim folklorem. „Driennik Zachodni $i^{* 6}$. 
groups which visited Rzeszów as many as 10 times, only once fewer than Krakowiak from Boston and Piastowie from Stockholm, Sweden which made its name of the festival veteran. ${ }^{45}$

In 2014 the group celebrated its $60^{\text {th }}$ anniversary. Covering the event, Zatorski expressed the opinion that in terms of its artistic heritage, it has influence on making a connection between the Polish and Czech culture. Recollecting, he underlined that the performance of the group during the first editions of the festival was much better than the others. ${ }^{46}$ The award and a great honor for the group was participating in the festival in 2017 when the dancers Elżbieta Palowska and Gabriel Kopec were granted the symbolic key to the city by the President of Rzeszów. ${ }^{47}$ It was also mentioned by the local press that Olza received the highest distinctions, that is the Oskar Kolberg Award and the Józef Ligon Award which made its visits in the Podkarpackie Province even more important. ${ }^{48}$

Olra was not the only guest to the festival. Since 1953, the group of Suszanie has been actively performing the songs and dances of the Cieszyn Silesia, the middle of the Cieszyn neighborhood, the west of Orłowa, Karwin and Bogumin. The Song and Dance Group of Suszanie started its activity within the Local Association of Polish Culture and Education in the Czech Republic. The group performed the dances of Slovakia, the Czech Republic but also the Polish regional and national dances. In 2019 it was their ninth visit to the World Festival of the Polish community Folk Groups in Rzeszów, the seventh in a row. In 2017 they took the lead of the Closing Concert called the Folklore of the Peoples of the World, making other participants follow them up with the collection of the folk dances from Bytom. ${ }^{49}$ Rzeszów was also visited by the group of Bledowice, started in 1983 in Błędowice, a district of Hawierzów, the Czech Republic. Since 1989 it has been accompanied by the Kamraci band which presents the folklore of the Silesia region and that of mining. Since 2019, the repertoire has also included a suite of the Czech dances. As stated in the catalogue, the groups from Błędowice, Sucha Górna

45 Wais, L. (2008). Festiwale Polonijne w Rzeszowie. „Echo Rzeszowa“, nr 7, p. 7; Zatorski, R. Polonia z macierza. XIV Światowy Festiwal Polonijnych Zespołów Folklorystycznych Rzeszów 2008. „Nasz Dom Ržeszón: miesięcznik społeczno-kulturalny“, nr 7, pp. 3-4.; Zatorski, R. (2017). Zachowują i odradzają polskość. XVII Świtowy Festiwal Polonijnych Zespołów Folklorystycznych. „Nasそ. Dom Ržeszón: miesiecznik spoteczno-kulturalny“, nr 7, p. 3.

46 Zatorski, R. (2014). W korowodzie i na estradach. 16. Światowy Festiwal Polonijnych

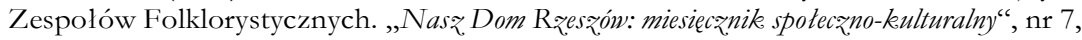
p. 3.

47 Zatorski, R. Korzenie naszej kultury..., p. 3.

${ }^{48}$ Kwoczyński, W. (2017). Na swojską nutę. Echa XVII Światowego Festiwalu Polonijnych Zespołów Folklorystycznych Rzeszów 2017. „Trz̧cionka: kwartalnik społecそno-kulturalny Samorzadu Gminy Świlcza $i$ Gminnego Centrum Kultury, Sportu $i$ Rekreacii w Świlcay z siedriba w Trzianie“, nr 83, p. 67.

49 Zatorski, R. Korzenie naszej kultury..., p. 3. 
and the Czech Cieszyn represented the Polish community from the Czech Republic from 17 to 25 of July 2019 in Rzeszów. ${ }^{50}$

\section{The signs of the Polish-Czech integration}

As 20 years have passed since the first festival in Rzeszów, it was written in the press that the generation gap became noticeable since some of the groups were managed by the children of the first dancers. ${ }^{51}$ The personal integration became a reality expressed by the relationships, the marriages of the dancers or their children being born. For instance, in the group of Piastowie from Sweden one of the dancers, is Katarzyna whose parents met during the festival in 1983.

Her mum was dancing in Olza whereas her dad was dancing in Piastowie. ${ }^{22}$ In 2011 during the XV festival taking place in Kazimierz Dolny upon Vistula River there was the whole group of Karolina from Great Britain to witness to the wedding of the two dancers from the group. In a few days during the Closing Concert called the Polish Wedding 1200 dancers from 43 countries and 4 continents were singing and dancing for the newly-wed. ${ }^{53}$

The good relations between the Poles and the Czech were expressed by the title of the press article published in Nowiny in 1993, Our friends from the Crech Republic. It indicated the virtues of the groups of Olza, Górnik and Btédowice which also gave a concert in the Polish village of Soleczniki, Lithuania. It was mentioned that the festival was about to host the local group of Lysznica from Leszna Dolna for the first time, despite being it in operation for a few years. They were to perform the Midsummer Eve, Ondraszek, the Silesia bandit and the collection of the dances of Żywiec. ${ }^{54}$ As the example of conveying of cultural values that is folklore, in 1993 the group of Mtode Btedowice performed the dance of the Gypsies from Orava. ${ }^{55}$ The similar opinion was expressed about other groups from Zaolzie as those presenting high artistic level. ${ }^{56}$

The festival from the very beginning was accompanies by a numerous events as popular as the dances themselves. An extremely emotional moment for the group members and the audience alike, widely covered by the local press, was the Contest for the Nicest Girl of the World Festival of the Polish community groups. As stated in the catalogue of 1969, the contest winner became Teresa Borysewicz from the group of Krakowiak from Boston and the second place went to Ewa Molin from Olza. ${ }^{57}$ In 1972 the queen of smile title went to Jadwiga Palowska from

\footnotetext{
50 Folder XVIII Światowego Festiwalu Polonijnych Zespotów Folklorystycznych (2019), p. 2.

51 Szymczyk, W. (1989). Na gorąco o festiwalu. „Widnokrag“, nr 30, p. 1.

52 http://wspolnota-polska.rzeszow.pl/stowarzyszenie/historia/, dostęp z dnia 6 XI 2019.

53 Gieroń, A. Hejprayjechali..., p. 1.

54 Nasi z Czech. „Nowiny“, p. 1.

55 Polonia coraz młodsza. „Nowiny“, p. 1.

56 Waiss, L. Zamiast rapu obertas. „Panorama“, p. 1.

57 ADRP, sygn. T-078, I ŚFPZF, Folder informacyjny 1969, k. 18.
} 
the Soong and Dance Group of Gornik from Karwiny. ${ }^{58}$ In 1989 on the pages of Windokrag, there was a picture of Renata Górecka, the beauty queen of the Polish communities from Czechoslovakia taken by Tomczyk. ${ }^{59}$ Unfortunately, in 2008 the idea of the contest came to an end. As pointed out by Gazeta Wyborcza, the decision was not welcome by the audience. As the reason of not holding the contest anymore, Mariusz Grudzień, the director of the festival indicated the difficulty in selecting the representative of each group. It should also be mentioned that the name of the competition Miss Polonia was restricted by the Polish television. Thus, the organizers were afraid that the verdict would cause a lot of controversy, being rather a bone of contention than an integrating factor which was the main idea of the festival. ${ }^{60}$

The press stressed that coming of the groups, building new contacts became the source of inspiration to take further action and to organize concerts of folk music in other cities of the Podkaprackie. ${ }^{61}$ For instance, thanks to participating in the International Festival of Folklore and the contacts built, the Song and Dance Group of Rochy from Sedziszów Malopolski was able to organize the International Folklore Meetings in there. In 2007 it was attended, among the others, by the group of Slezanie from the Czech Republic. ${ }^{62}$ Going to give the concerts in different cities of the Podkarpackie region, was also a chance to spend this time together. The added value became the established contacts, friendships made on the way or relationships which made the joint ventures possible. In 1983 the groups of the Polish communities coming to the VI festival from the camps in Cracow and Lublin were than welcome. The group from the former Czechoslovakia was based in Lublin and then, arrived in Sedziszów Malopolski63. In 1989 it was noted that in the rooms of the Sanitarium in Iwonicz Zdrój there were some informal meetings and learning to sing songs together. ${ }^{64}$ In 1996 during the $\mathrm{X}$ festival after the Closing Concert, during the warm summer night of July, the participants started dancing on the football stadium in Rzeszów which turned into a mass event. ${ }^{65}$ In 1999 the group of Slezan from the Czech Republic

58 ADRP, sygn. T-078, II ŚFPZF, k. 12. Jadwiga Palowska ,królowa uśmiechu“ II ŚFPZA

59 W obiektywie fotoreporterów (1989). ,Widnokrag“, nr 30, p. 2.

60 Kulczycka, A. (2008). Festiwal bez wyborów miss? „Gazeta Wyborcza“, p. 1.

${ }^{61}$ Kwoczyński, W. (2012). Historia kontaktów zagranicznych „Rochów“ i „Pułanów“ (2007-2012), „Trzcionka: kwartalnik spotecæno-kulturalny Samorzqdu Gminy Świlczai Gminnego Centrum Kultury w Świlczy z siedziba w Trz̧cianie“, nr 63, p. 35; Sudyka, R. (2009). Tożsamość tańcem i śpiewem zapisana. „Croscena: krośnienskka scena kultury“, nr 69, p. 10.

${ }^{62}$ Kwoczyński, W. Historia kontaktów zagranicznych..., p. 35.

${ }^{63}$ VI Festiwal Polonijnych Zespołów Folklorystycznych - otwarty (1983). „Nowiny: dziennik Polskiej Zjednoczonej Partii Robotniczej", nr 167, p. 2.

${ }^{64}$ Biskup, B. (1989). Przybywamy z najdalszych ziemi stron. „Widnokrag“, nr 29, p. 2.

${ }^{65}$ Furman, W. (1996). Festiwal Polonijny w Rzeszowie. Swing i oberek. „Fraza: poezja, proza, esej", R.6, nr 14, p. 204. 
came to the international folklore meetings in Sedziszów. ${ }^{66}$ The established relations became much closer by inviting someone to be one's guest. ${ }^{67}$ Being dancing the most natural form of expression contributed to making friends. ${ }^{68}$ As observed by the author of the press article published in the local newspaper in Lańcut, the municipalities and the local governments, the residents were more and more interested in the festival but also in hosting the groups. ${ }^{69}$

One of the most important parts of the festival were trips and sightseeing of the Podkarpackie region. They aimed at integrating both the organizers and the participants and contributed to making contacts with the locals but not only. In the time of the Polish People's Republic in particular, it was especially important to the press to visit sights of industrial and cultural purpose of the Rzeszów region, informal meetings and talks with the crew as well as becoming familiar with the landmarks of the local architecture (among the others, of Lańcut, Krasiczyn, Leżajsk, Jarosław).

As concluded on the basis of the analysis of the source material, the most popular were trips to the Bieszczady. Before the III festival in 1974, the group of Olza from Cieszyn, Kujawy from Montchanin and Ślask from Lyon, France were hosted in Wrocław. A group of 110 participants visited, among the others the workplace of Hetman and Jelcz in Lower Silesia and the company of automotive electrical systems (ZEM) in Swidnica. ${ }^{70}$ In 1989 the groups practiced under the guidance of the Polish choreographers and then, visited the former Krosno Province (Krosno, Jasło, Sanok, Bóbrka, Odrzykoń, Rymanów) with the Krosno Glass Factory, the Podkarpackie Oil Refinery in Jasło, the company of Iglopol in Jasło, etc. Some of the groups performed in Iwonicz Zdrój and beyond. ${ }^{71}$ In the $21^{\text {st }}$ century. the trips crossing the eastern border of Poland were far more frequent. In 2008 some of the groups were visiting Lviev as it was the venue of a conference on folklore as a factor integrating the Polish communities with their homeland. ${ }^{72}$ As soon as the II festival, the press emphasized that about 800 young people from Europe and across the ocean brought to the country a special gift, namely Polish song and dance, the folklore of their ancestors but also of their own. Covering the festival in 1972, it was noted that the group of Gornik from Czechoslovakia was one of the guests. ${ }^{73}$ It was also said that the festival proved to

${ }^{66}$ Czapka, B. (2009). VI Międzynarodowe Spotkania Folklorystyczne. „Biuletyn Sędziszonskei”, nr 7, p. 1,8.

67 Zatorski, R. Polonia ₹.macierzq..., pp. 3-4.

${ }^{68}$ Dziedzic, Z. (2017). Gmina Świlcza folklorem stoi! „Trzcionka: kwartalnik społecznokulturalny Samorzqdu Gminy Świlcza i Gminnego Centrum Kultury, Sportu i Rekreaci w Świlczy z siedzibq w Trzcianie", nr 83, p. 63; pp. 62-63.

69 Hadław, R. (2019). Gmina Lańcut gościła zespół z Ukrainy. „Głos gminy Łańcut“, nr 8, p. 11.

70 Zespoły polonijne wystąpią w Sobótce i Wrocławiu. „Gažta Robotnicza“", p. 1.

71 Biskup, B. (1989). Przybywamy z najdalszych ziemi stron. „Widnokrag“, nr 29, p. 1.

72 Zatorski, R. Polonia z. macierzq..., p. 3.

73 Światowe spotkanie zespołów polonijnych (1972). „Tygodnik Polski i“, k. 4. 
be one of the best forms of building contacts between the Polish communities and the homeland but also a chance to present the culture of the Polish communities in other Polish cities to its residents using songs and dances of their own country. The growing number of visiting groups together with the eagerness of the audience to participate in the concert of the country of residence was the best way to see how successful the festival has become. ${ }^{74}$

Some of the events accompanying the festival are no longer there, it is enough to mention the art and sport ones which did not stand the test of time. In 1972 the football matches between the teams from Rzeszów and the rest of the world were accompanied by the folk songs of Poland, Hungary, Canada, the Netherlands, the US and the dances (Krakovyak, Kujawiak, the dances of Cieszyn and of Hungary). The female football team from Rzeszów lost whereas the male was more successful. Other sports events included the volleyball match, chess game, table tennis and snooker. ${ }^{75}$

The educational character of the festival was manifested by the competitions and quizzes about the host country, for instance, Know it all about Poland and the great Poles living abroad. The questions concerned history, geography, culture and Polish economy. In 1972, among the four finalists there was Alicja Kołcz from Olza. ${ }^{76}$

Expanding knowledge and improving language skills by the festival participants was possible thanks to the Nowiny project started in the 1960s. It was about collecting books to the Polish community libraries. ${ }^{77}$

Another important initiative during the festival was organizing fairs and exhibitions as well as the guest performance of other Polish folk groups. The fair of the folk art and handicraft took place in the market square in Rzeszów, being the local handicraft of special interest. ${ }^{78} \mathrm{It}$ is worth to mention that the tradition of organizing the fair preserved to this day so that in 2019 one can still buy local goods such as pre-packed groceries, the homemade products and handicraft included. The publications popularizing the Podkarpackie Province are also available. ${ }^{79}$ During the III festival in 1974, the exhibitions were held at the International Association of Book and Press. These were devoted to the sculpture and ceramics of the Rzeszów region as well as painting of Tibor Crosby, a Hungarian living in Warsaw and Olga Pasternak-Marszczyńska from

74 „Nowiny: driennik Polskiej Zjednoczonej Partii Robotniczej“ 1 VII 1980, nr 144, p. 1; Piątek, A. (1999). Wielki piknik. „Nowiny: gazeta codzienna“, nr 137, p. 6.

75 Wielka impreza artystyczno-sportowa na stadionie „Resovii““(1972). „Nowiny Ržeszowskie“, p. 2.

76 Uczestnicy festiwalu w Łańcucie i Leżajsku (1972). „Nowiny Rẓeszowskie“, p. 2.

77 Popow, J. (1983). Inicjatorzy polonijnego festiwalu. „Widnokrag: tygodnik spotecznokulturalny", nr 28, p. 1.

78 Piątek, A. Wielkipiknik..., p. 6.

79 http://wspolnota-polska.rzeszow.pl/jarmark-podkarpacki-2/, dostęp z dnia 30.01.2020. 
Argentina ${ }^{80}$ During the following festival events the idea to popularize the folk art and build contacts remained. In July 2019 there was an exhibition presenting the photographs and documents from the 50 years of the festival history. It was called A little bit of coincidence, a little bit of a need- the 50 years of the World Festival of the Polish community folk groups (1969-2019) and the interdisciplinary exhibition of the Voivoideship Cultural Centre called That's how it started. ${ }^{81}$ The next level of integration became the performance of the Polish art groups on the stage of the market square in Rzeszów. ${ }^{82}$ On 19 July there was also a presentation of songs and dances in other towns and cities of the Podkaprackie Province and in Poland. ${ }^{83} \mathrm{It}$ should be noted that, especially the press expressed the need to present not only the Polish folklore but also the songs and dances of the groups' countries of residence. ${ }^{84}$ The groups from abroad tried to keep performing the dances in the Polish cities on the same, high level but also the choreography to be of interest to the public. As mentioned in Biuletyn Sedziszowski, the audience during the performance of the Portuguese group at the International Folk Meetings in 2019 was not only intrigued by the dances themselves but also by the presence of the group of the elderly on stage covered with straw. In all likelihood, it was in there to suggest the theme of the performance, being it the dances and plays of the Portuguese farmers. ${ }^{85}$

In 2017 in Bratkowice, near Rzeszów there was an outstanding open-air performance of singing and dancing of Olza from the Czech Cieszyn, the Czech Republic with the traditional highlander band of Lipka from Jabłonkowo, the Czech Republic. ${ }^{86}$ The show was met with standing ovation resulting from the exuberant nature of the performance of the collection of the highlander songs and dances. It was complemented by the performance of the group and band called Stara Uherska and the bouncy dances of the Trenczyn region.

The meetings and workshops organized for the members of the groups in more than 20 cities in Poland were of special educational value. They lasted even up to 2 and became an integral part of the festival agenda, usually held before or after it. When the festival started, the groups needed the substantive support of ethnographers, choreographers and musicians. To begin with, the consultation took place during the festival but from 1977 to 1989 the so-called camps before the festival were organized. To support the Polish community, Polish choreographers and dancers were relocated to different Polish community centers, the courses of

$80 \quad$ Dzieszyński, R. Siedem sz̨z̨ślinyych..., p. 47.

81 Folder festiwalowy XVIII Światowego Festiwalu Polonijnych Zespotów Folklorystycznych w Rzeszowie 17-25 lipca 2019, p. 2.

82 Gieroń, A. Hejprayjechali..., p. 1.

83 Folder festiwalowy XVIII Światowego..., p. 2.

84 Szymczyk, W. Na goraco..., p. 1.

85 Czapka, B. VI Miedzynarodowe Spotkania..., p. 1,8.

86 Kwoczyński, W. Na swojskq nute..., s. 66-69. 
folk dances and national dances were organized both for the choreographers and the groups. The next step was creating the Choreographic Centre. As mentioned before, in Rzeszów the classes are conducted by the 4-year Choreographic Centre and the Centre for the Polish Dancers where the Polish community folk groups can improve their skills and qualifications. ${ }^{87} \mathrm{~A}$ very important part of the Centre programme is organizing numerous events of cultural and educational character as they are both to educate and integrate. The route comprises the centers of folk culture in the Podkarpackie Province. ${ }^{88}$

The recollections and the articles included in the magazines and the newspapers clearly show how important or even crucial folklore is for those who are into it. Often, other things become of lesser importance as they devote all time and energy to mastering their skills. By accepting the culture of one's own country of residence, the Polish community does not reject but cherish the culture of their ancestors.

M. Grudzien underlined that the festival, apart from Dolina Lotnicza and the Bieszczady, has become one of the most recognizable brands of the Podkarpackie abroad.89 Described as timeless, the event organized since 1969 and held every three years in July in Rzeszów, attracts thousands of visitors under the same brand of folklore. To every participant, organizer and the member of the audience it means something different but the feeling of being a part of something special and the element of integration have always been there, only on a different level. One of few groups which could be seen performing from the very beginning remains the Song and Dance Group of Olza from the Czech Republic. Over 50 years it was able to show both to the audience and the jury its high artistic value. Friendships and contacts were also made by other groups from the Czech Republic which were hosted not only in Rzeszów but also in other festivals and meetings in the Podkarpackie region and in Poland with its singing and dancing. The analysis of the source material as well as the content of the press articles published nationally but in the local magazines and newspapers in particular, makes it clear that folklore contributed to the Polish-Czech integration in so many dimensions, personal, linguistic, educational, cultural and behavioral.

87 Grudzień, M. (2006). Festiwal ponadczasowy. Rzeszów stolica polonijnego folkloru. „Nasz. Dom Rz̨eszón: miesięrznik spoteczno-kulturalny“, nr 7, p. 14.

89 Rogowski, G. (2011). Polonia znów opanuje Rzeszów. „DaynNight‘, nr 31, p. 14. 